Jurnal Ilmiah Ibnu Sina, 6(1), Maret 2021, 117-125

p-ISSN: 2502-647X; e-ISSN: 2503-1902

\title{
PENENTUAN AKTIVITAS TABIR SURYA DAN ANTIOKSIDAN EKSTRAK ETANOL BENALU (Henslowia frutescens) INANG JERUK BALI SECARA IN VITRO
}

\author{
Henny Nurhasnawati ${ }^{1}$, Rusdiati Helmidanora ${ }^{1}$, Yullia Sukawaty ${ }^{1}$, Andri \\ Priyoherianto $^{2}$, Elly Purwati ${ }^{2}$ \\ ${ }^{1}$ Sekolah Tinggi Ilmu Kesehatan Samarinda \\ ${ }^{2}$ Akademi Farmasi Mitra Sehat Mandiri Sidoarjo \\ Email ${ }^{1}$ : hennynurhasnawati@gmail.com \\ Email ${ }^{2}$ : tremenza_andri@yahoo.com
}

Artikel diterima: 15 Januari 2021; Disetujui: 27 Februari 2021

DOI: https://doi.org/10.36387/jiis.v6i1.647

\begin{abstract}
ABSTRAK
Benalu inang jeruk bali (Henslowia frutescens) merupakan tumbuhan semiparasit, meskipun dianggap merugikan namun berpotensi dimanfaatkan sebagai obat dan kosmetik. Tumbuhan ini diketahui memiliki kandungan senyawa metabolit sekunder yaitu senyawa fenolik, flavonoid, saponin, tanin, dan steroid sehingga memiliki aktivitas antioksidan yang tinggi. Tujuan penelitian ini adalah untuk mengetahui aktivitas tabir surya ekstrak etanol benalu inang jeruk bali berdasarkan nilai SPF (Sun Protecting Factor) secara in vitro serta mengetahui aktivitas antioksidan. Tahapan penelitian meliputi determinasi sampel, pengambilan sampel, ekstraksi secara maserasi dengan etanol 95\%, perhitungan rendemen, skrining fitokimia, uji aktivitas tabir surya berdasarkan nilai SPF, uji aktivitas antioksidan. Analisis data dilakukan secara deskriptif berdasarkan hasil pengukuran yang diolah sesuai rumus perhitungan. Hasil penelitian menunjukkan aktivitas tabir surya ekstrak etanol benalu inang jeruk bali berdasarkan nilai SPF secara in vitro diperoleh sebesar 14,57 - 25,20 dengan kategori proteksi sedang. Aktivitas antioksidan ekstrak etanol benalu inang jeruk bali menunjukkan kategori sangat kuat dengan nilai IC 50 sebesar 22,82 $\pm 1,33$.
\end{abstract}

Kata kunci: Antioksidan, Henslowia frutescens, SPF

\begin{abstract}
Henslowia frutescens is a semi-parasitic plant, although considered harmful, it has medicinal and cosmetic potential. This plant has secondary metabolite compounds, namely phenolic compounds, flavonoids, saponins, tannins, and steroids which have high antioxidant activity. The purpose of this study was to determine the sunscreen activity of the ethanol extract of Henslowia frutescens based on the in vitro SPF (Sun Protecting Factor) value and to determine its antioxidant activity. The research stages included sampling, sampling, maceration extraction with $95 \%$ ethanol, yield calculation, phytochemical screening, sunscreen activity test based on SPF value, and antioxidant activity test. Data analysis was carried out descriptively based on the
\end{abstract}


Jurnal Ilmiah Ibnu Sina, 6(1), Maret 2021, 117-125

p-ISSN: 2502-647X; e-ISSN: 2503-1902

measurement results processed according to the calculation formula. The results showed that the sunscreen activity of the ethanol extract of Henslowia frutescens based on the in vitro SPF value was 14.57 - 25.20 with moderate protection category. The antioxidant activity of the ethanol extract of Henslowia frutescens showed a very strong category with an IC value of $22.82 \pm 1.33$.

Keywords: antioxidants, Henslowia frutescens, $S P F$

\section{PENDAHULUAN}

Indonesia sebagai salah satu negara di Asia tenggara yang memiliki iklim tropis dengan suhu hangat dan sinar matahari menyinari sepanjang tahun. Sinar matahari mengandung sinar ultraviolet A (UVA), ultraviolet B (UVB) dan ultraviolet C (UVC). Sinar UVB memiliki manfaat dalam memproduksi vitamin D3 pada tubuh manusia dan penyebab timbulnya kanker kulit. Secara alami kulit sistem pertahanan dari paparan sinar matahari seperti proses pembentukan melanin, pengeluaran keringat dan penebalan pada scratum corneum. Paparan sinar matahari yang cukup lama dan terus menerus membuat jaringan epidermis kulit tidak dapat melawan efek negatif dari sinar matahari sehingga menyebabkan kulit terbakar dan eritema, terjadi penuaan dini serta kanker kulit (Ismail I. dkk, 2014). Bahaya pada kulit karena paparan lama sinar UV yang paling sering terjadi adalah non melanoma skin cancer (NMSC)(hanriko R dan hayati S.J, 2019).

Untuk menghindari terjadinya efek negatif dari radiasi sinar UV dapat dilakukan dengan penggunaan tabir surya. Penggunaan tabir surya dapat melindungi kerusakan DNA dan fotokarsinogenesis, mampu mencegah perkembangan kanker kulit (melanoma) yang dipicu oleh UV dengan mengurangi pembentukan dimer cyclobutane-pyrimidine serta pencegahan efek hipersensitivitas (Schalka S dan Reis V.M.S.D, 2011). Efektifitas dari tabir surya didasarkan pada penentuan nilai sun protection factor (SPF) yang menunjukan kemampuan produk tabir surya dalam melindungi kulit dari paparan sinar UV. Nilai SPF besar atau kecil dipengaruhi oleh kandungan antioksidan dari bahan aktif yang digunakan dalam membuat sediaan tabir surya (Stanfield, J.W, 2003).

Tanaman jeruk Bali secara empiris digunakan masyarakat untuk 
Jurnal Ilmiah Ibnu Sina, 6(1), Maret 2021, 117-125

p-ISSN: 2502-647X; e-ISSN: 2503-1902

mengobati berbagai macam penyakit seperti diabetes, kanker, radang sendi, hipertensi dan lain-lain. Berdasarkan dari hasil penelitian tanaman jeruk bali memiliki aktivitas antiradikal bebas pada ekstrak buah (Navitri D, 2012). Kulit buah jeruk bali memiliki aktivitas antibakteri (Wana $\mathrm{N}$ dan Pagarra H,2019). Daun jeruk bali mengandung senyawa bioaktif yang dapat memperbaiki sel beta pankreas dan meningkatkan sensitifitas insulin (Zhafira A, 2019) dan lain-lain. Pemanfaatan tanaman benalu telah digunakan sejak lama untuk terapi kanker yaitu viscum album, benalu teh sebagai anti malaria dan kandidat obat kanker, ektrak benalu jeruk nipis untuk penyakit ambein dan diare, benalu kapas sebagai antimikroba. Daun benalu merupakan tanaman parasit terhadap inangnya, benalu mengambil nutrien dan senyawa pertahanan diri dari tumbuhan inang tempat tumbuhnya, hal ini akan menyebabkan perbedaan kandungan metabolit sekunder pada tanaman benalu jika inangnya berbeda. Metabolit sekunder seperti flavonoid, alkaloid, saponin, tanin dan lain-lain yang memiliki peranan penting dalam perlindungan terhadap sinar matahari (Maheshwar.G.H,dkk.2010).

Bagaimana aktivitas ektrak etanol benalu inang jeruk bali berperan sebagai tabir surya di ukur dari nilai SPF, tujuan peneliti ingin mengetahui aktivitas tabir surya ekstrak etanol benalu (Henslowia frutescens) inang jeruk bali berdasarkan nilai SPF secara in vitro.

\section{METODE PENELITIAN}

Penelitian ini adalah penelitian eksperimental, dengan pengambilan sampel secara purposive sampling. Sampel yang digunakan adalah benalu inang jeruk bali yang diperoleh di Kampung Dilang Puti Kecamatan Bentian Besar Kabupaten Kutai Barat. Determinasi dilakukan di laboratorium anatomi dan sistemaika tumbuhan fakultas MIPA Universitas Mulawarman Samarida. Pembuatan simplisia diawali dengan sortasi basah, pencucian dengan air mengalir untuk menghilangkan kotoran yang menempel dan dikeringkan dengan dianginkan serta terlindung dari sinar matahari langsung. Selanjtnya simplisia dihaluskan dengan menggunakan blender. Ekstrak benalu 
Jurnal Ilmiah Ibnu Sina, 6(1), Maret 2021, 117-125

p-ISSN: 2502-647X; e-ISSN: 2503-1902

inang jeruk bali di peroleh dengan cara ektraksi 600 gram simplisia dalam 3 liter pelarut etanol 95\% secara maserasi dan remaserasi, selanjutnya maserat diuapkan dengan rotary evaporator pada suhu $60^{\circ}$ Chingga didapatkan ekstrak kental. Skrining fitokimia terdiri atas Alkaloid $(0,5$ gram sampel $+1 \mathrm{ml}$ asam klorida $2 \mathrm{~N}$ + $9 \mathrm{ml}$ air suling, dipanaskan 2 menit pada penangas air, filtrat diuji dengan pereaksi meyer, bouchardat dan dragendorf), fenolik (metode FolinCiocalteau), flavonoid (2 gram sampel $=20 \mathrm{ml}$ air panas, didihkan 5 menit disaring, $5 \mathrm{ml}$ filtrat $+0,1 \mathrm{~g} \mathrm{MG}+1$ $\mathrm{ml} \mathrm{HCL}+2 \mathrm{ml}$ amil alkohol), tannin $(0,5 \mathrm{~g}$ sampel $+10 \mathrm{ml}$ Aquades, disaring + aquadest hingga tidak berwarna, ambil $2 \mathrm{ml}+1-2$ tetes $\mathrm{FeCl}_{3}$ $1 \%)$ saponin $(0,5 \mathrm{~g}+10 \mathrm{ml}$ air suling panas, kocok kuat 10 detik) dan steroid/terpenoid ( $1 \mathrm{~g}$ sampel $+20 \mathrm{ml}$ n-Heksan dipanaskan 2 jam, diuapkan, filtrat +2 tts asam Asetat anhidtat +1 tts $\mathrm{H}_{2} \mathrm{SO}_{4}$ ). Pengukuran aktivitas tabir surya dengan alat spektrofotometer UV-Vis (Shimadzu UV-1800) pada absorbansi 290-320 nm dengan interval $5 \mathrm{~nm}$, pengujian dilakukan dengan replikasi 3 kali untuk masing- masing konsentrasi, perhitungan SPF mengikuti persamaan Mansur. Penentuan aktivitas antioksidan mengunakan metode DPPH dengan senyawa pembanding vitamin $\mathrm{C}$, seri konsentrasi yang dibuat 10, 20, 30, 40 dan $50 \mathrm{ppm}$ untuk larutan sampel dan 2, 4, 6, 8 dan 10 ppm untuk larutan vitamin C. Penentuan panjang gelombang maksimum dilakukan dengan mengukur absorbansi larutan DPPH 40 ppm menggunakan spektrofotometer UV-Vis pada panjang gelombang 450-600 nm., masing-masing seri larutan diukur absorbansinya kemudian dicari nilai \% inhibis. Analisis data dilakukan secara deskriptif berdasarkan hasil pengukuran yang diolah sesuai rumus perhitungan dari masing-masing parameter. Semua data dibuat dengan tiga kali replikasi dan dinyatakan sebagai $\bar{x} \pm$ SD.

\section{HASIL DAN PEMBAHASAN}

Randemen yang diperoleh dari 600 gram serbuk simpliasia dengan total pelarut etanol 95\% sebanyak 6 liter (termasuk remaserasi) sebesar $3,42 \%$ dan berat ekstrak 20,49 gram. 
Jurnal Ilmiah Ibnu Sina, 6(1), Maret 2021, 117-125

p-ISSN: 2502-647X; e-ISSN: 2503-1902

Tabel 1. Hasil Skrining Fitokimia

\begin{tabular}{|c|c|c|c|}
\hline Metabolit sekunder & Pereaksi & Pustaka & Hasil \\
\hline \multirow[t]{3}{*}{ Alkaloid } & Mayer & Endapan putih/kuning & $(+)$ \\
\hline & Bouchardat & Endapan coklat-hitam & $(-)$ \\
\hline & Dragendorf & Endapan merah bata & $(+)$ \\
\hline Fenolik & $\mathrm{FeCl}_{3} 1 \%$ & $\begin{array}{l}\text { Warna hijau/merah/ungu/ } \\
\text { biru/hitam kuat }\end{array}$ & $(+)$ \\
\hline Flavonoid & Amil alkohol & Warna merah/jingga pada lapisan amil alkohol & $(+)$ \\
\hline Tanin & $\mathrm{FeCl}_{3} 1 \%$ & Larutan hijau kehitaman & $(+)$ \\
\hline Saponin & $\mathrm{HCl} 2 \mathrm{~N}$ & Busa $1-10 \mathrm{~cm}$ & $(+)$ \\
\hline Steroid/terpenoid & $\mathrm{H}_{2} \mathrm{SO}_{4}$ pekat & Biru kehijauan & $(+)$ \\
\hline
\end{tabular}

Keterangan: $(+)=$ terdeteksi $(-)=$ tidak terdeteksi

Hasil Skrining fitokimia pada ekstrak etanol $95 \%$ benalu inang jeruk bali diketahui bahwa golongan senyawa yang terkandung di dalamnya adalah alkaloid, fenolik, flavonoid, tannin, saponin dan steroid/terpenoid. Hasil penelitian ini berbeda dengan penelitian Leditalia (2019) pada jenis simpliasia yang sama menggunakan pelarut etanol $70 \%$, dimana tidak terdapat golongan senyawa alkaloid dan sapoin. Golongan senyawa yang terkandung adalah fenolik, flavonoid, tannin dan steroid/terpenoid (Leditalia,2019). Pada ekstrak dengan alkohol $70 \%$ alkaloid tidak terdekteksi hal ini dapat dipengaruhi dari sifat alkaloid yang basa dan larut dalam pelarut organik hanya alkaloid garam yang larut dalam air dan alkaloid akan mudah di deteksi jika di ekstrak dengan menggunakan etanol $80 \%$ atau lebih sebagaimana metode Wall dan metode Kiang-Douglas.

Penentuan aktivitas tabir surya berdasarkan nilai SPF dilakukan secara in vitro menggunakan metode spektrofotometri UV-Vis pada rentang panjang gelombang dari $290 \mathrm{~nm}$ sampai 320 nm. Pengukuran absorbansi sampel dilakukan tiap 5 nm. Dari 3 kali pengukuran di peroleh absorbansi yang cendrung sama.

Dari data absorbansi yang diperoleh dilanjutkan perhitungan nilai SPF. Nilai SPF pada penelitian ini berbanding lurus dengan konsentrasi ekstrak, semakin besar konsentrasi ekstrak, maka akan semakin meningkatkan nilai SPF. 
Jurnal Ilmiah Ibnu Sina, 6(1), Maret 2021, 117-125

p-ISSN: 2502-647X; e-ISSN: 2503-1902

Tabel 2. Nilai SPF Ekstrak Etanol Benalu Inang Jeruk Bali

\begin{tabular}{cccccc}
\hline Konsentrasi (ppm) & I & II & III & Rata-rata & Kategori \\
\hline 600 & 15,32 & 15,37 & 13,03 & $14,57 \pm 1,33$ & Proteksi \\
700 & 17,69 & 17,66 & 15,02 & $16,79 \pm 1,53$ & Sedang \\
800 & 21,54 & 21,51 & 17,24 & $20,10 \pm 2,47$ & \\
900 & 23,99 & 23,99 & 19,86 & $22,61 \pm 2,38$ & \\
1000 & 27,10 & 26,62 & 21,89 & $25,20 \pm 2,88$ & \\
\hline
\end{tabular}

Ekstrak mengandung beberapa senyawa kimia, diantaranya adalah senyawa fenolik dan flavonoid sebagai bahan aktif tabir surya. Menurut penelitian yang dilakukan oleh Wolf $e t$ al (2001) senyawa flavonoid sebagai tabir surya bekerja dengan cara menyerap sinar yang masuk ke kulit sehingga dapat mengurangi kerusakan kulit yang disebabkan sinar ultraviolet.

Uji aktivitas antioksidan secara kuantitatif dilakukan dengan menggunakan metode DPPH. Parameter dalam pengukuran ini adalah $\mathrm{IC}_{50}$, dimana besarnya aktivitas antioksidan untuk menghambat $50 \%$ radikal bebas. Nilai $\mathrm{IC}_{50}$ yang semakin kecil menunjukkan bahwa aktivitas antioksidan semakin besar dalam menghambat radikal bebas (Pratiwi, 2013).

Tabel 3. Nilai $\mathrm{IC}_{50}$ Ekstrak Etanol Benalu dan Vitamin C

\begin{tabular}{lll}
\hline Bahan & IC50 $_{\mathbf{5 0}}(\mathbf{p p m})$ & $\begin{array}{l}\text { Rata-Rata } \\
(\mathbf{p p m})\end{array}$ \\
\hline Ekstrak & 21,34 & $22,82 \pm 1,33$ \\
Etanol Daun & 23,90 & \\
Benalu & 23,23 & \\
Vitamin C & 8,52 & $8,94 \pm 0,93$ \\
& 8,30 & \\
& 10,01 & \\
\hline
\end{tabular}

Hasil penelitian menunjukkan nilai $\mathrm{IC}_{50}$ sebesar $22,82 \pm 1,33 \mathrm{ppm}$ dengan kategori sangat kuat, seperti vitamin C. Hasil ini sesuai dengan penelitian Delasni (2019) pada ekstrak etanol $70 \%$ benalu inang jeruk bali yaitu diperoleh nilai $\mathrm{IC}_{50}$ sebesar 35,6269. Semakin banyak metabolit sekunder yang dikandung, maka semakin kuat aktivitas antioksidannya (Bahriul, 2014). 
Jurnal Ilmiah Ibnu Sina, 6(1), Maret 2021, 117-125

p-ISSN: 2502-647X; e-ISSN: 2503-1902

\section{Uji ke-1}

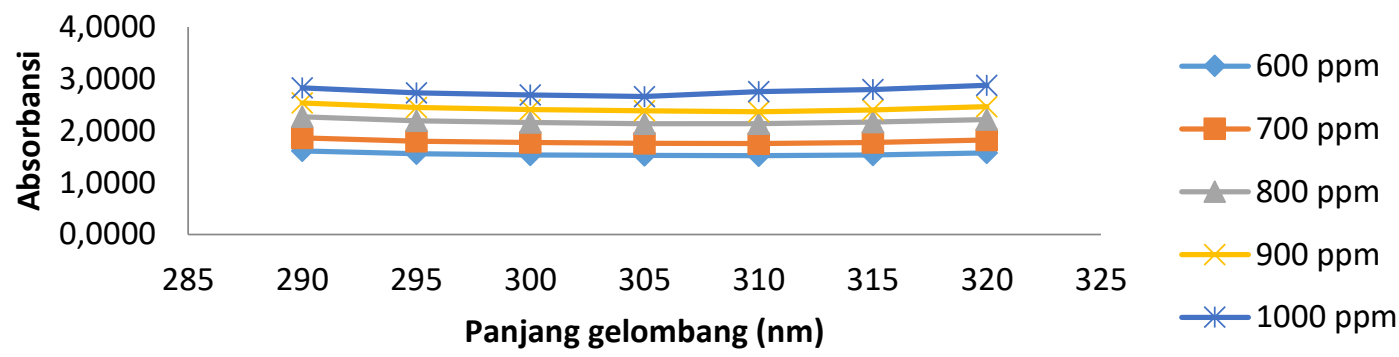

Uji ke-2

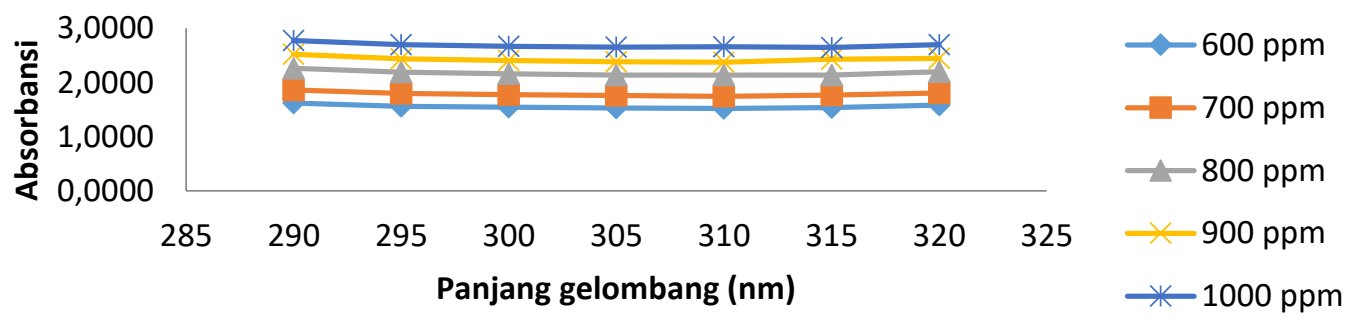

Uji ke-3

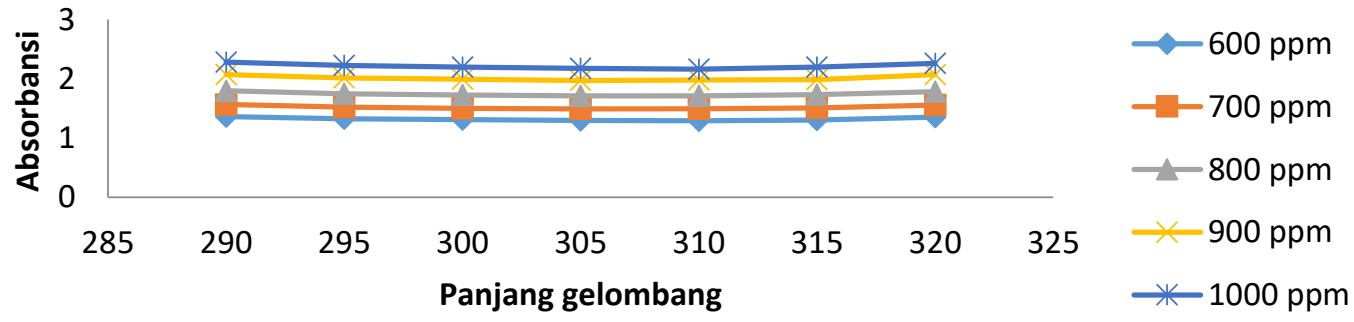

Gambar 1. Absorbansi Ekstrak Etanol Benalu Pada Panjang Gelombang 290$320 \mathrm{~nm}$

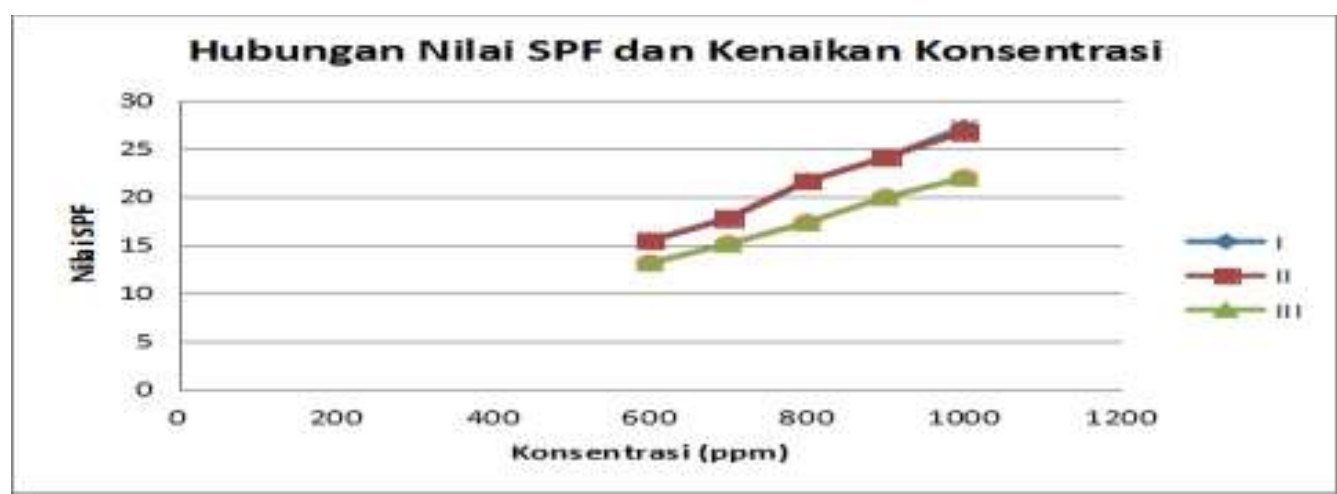

Gambar 2. Hubungan Nilai SPF dan Kenaikan Konsentrasi Etanol 
Jurnal Ilmiah Ibnu Sina, 6(1), Maret 2021, 117-125

p-ISSN: 2502-647X; e-ISSN: 2503-1902

\section{KESIMPULAN}

Ekstrak etanol 95\% benalu inang jeruk bali memiliki senyawa alkaloid, fenolik, flavonoid, tannin, saponin dan steroid/terpenoid. Senyawa fenolik dan flavonoid berperan sebagai bahan aktif tabir surya. Aktivitas tabir surya ekstrak etanol benalu (Henslowia frutescens Champ) inang jeruk bali berdasarkan nilai SPF secara in vitro diperoleh sebesar $14,57 \quad-25,20$ dengan kategori proteksi sedang. Aktivitas antioksidan ekstrak etanol benalu inang jeruk bali menunjukkan kategori sangat kuat dengan nilai $\mathrm{IC}_{50}$ sebesar 22,82 $\pm 1,33$.

\section{UCAPAN TERIMAKASIH}

Terimakasih kepada LPPM STIKSAM atas pendanaan yang diberikan.

\section{DAFTAR PUSTAKA}

Bahriul, P., Rahman, N., dan Diah, A.W. 2014. "Uji Aktivitas Antioksidan Ekstrak Daun Salam (Syzygium polyanthum) dengan Menggunakan 1,1Difenil-2-Pikrilhidrazil", Jurnal Akademika Kimia, Vol. 3, no.3, hal. 143-149.

Hanriko, R \& Hayati, S. J., 2019, "Non-Melanoma Skin Cancer (NMSC) pada Pekerja Luar Ruangan dan Intervensinya" $J$
Agromedicine, Vol. 6, No.2, Hal. 405-409.

Leditalia, 2019. "Penetapan Kadar Senyawa Fenolik Total Ekstrak Etanol Daun Dan Ranting Benalu (Henslowia Frutescens Champ.) Inang Jeruk Bali Secara Spektrofotometri UV-Vis". KTI. Samarinda: Sekolah Tinggi Ilmu Kesehatan Samarinda.

Maheshwar, G. H., Patil B. S, Prashant, D., 2010, "Comparative Sun Protection Factor Determination of Fresh Friuts Extract Cucumber vs Marketed Cosmetic Formulation", RJPBCS, Vol.1, No.3, Hal. 55-59.

Navitri,D.A., Monica.M., 2012, "uji aktivitas antiradical beba ekstrak buah jeruk bali (Citrus maxima Burm.Fz) dengan metode DPPH (1,1-diphenyl-2-

Pikrylhidrazyl)", UNESA Journal Of Chemistry, Vol. 1, No.2.

Pratiwi, D., Wardaningsih, S., dan Isnindar, 2013, "Uji Aktivitas Antioksidan Daun Bawang Mekah (Eleutherine americana Merr) Dengan Metode DPPH (2,2-Difenil-1-Pikrilhidrazil)", Traditional Medicine Journal, 18 (1): 9-16.

Schalka, S., Reis, V. M. S. D., 2011. "Sun Protection Factor: Meaning and Controversies". Anais Brasileiros de Dermatologia. 86 (3): 507-15.

Stanfield,J.W., 2003, "Sun Protectans: Enhancing product functionality with sunscreen", in schueeller,r. and romanowski,P. 
Jurnal Ilmiah Ibnu Sina, 6(1), Maret 2021, 117-125

p-ISSN: 2502-647X; e-ISSN: 2503-1902

multifunctional cosmetic, New York: Marcel Dekker Inc.

Wana,N., Pagarra,H., 2018, "Efektifitas Ekstrak Pektin dari kulit buah jeruk bali (Citrus maxima) sebagai antimikroba", Bionature, Vol. 19, no 2, Hal. 140-151,

DOI: $\underline{10.35580 / \text { bionature.v19i2. }}$ $\underline{9732}$

Wolf, R., Wolf, D., Morganti, P., Ruocco, V, 2001,
"Spectrophotometric Analysis And Modeling Of Sunscreens", Journal of Chemical Education, Hal. 99-102.

Zhafira.A. 2019 "Daun jeruk pamelo (Citrus maxima Merr) sebagai terapi diabetes mellitus", Jurnal Ilmiah Kesehatan Sandi Husada, Vol. 10, No.2, Hal. 202-206. DOI: https://doi.org/10.35816/ji skh.v10i2.148 